\title{
Aspects of Peacekeeping and Peace-Enforcement in Conflict Resolution: West Africa and the Congo
}

\author{
Bulus Nom Audu \\ Department Of History And International Studies, Nigeria Police Academy, \\ Wudil, Kano State
}

\begin{abstract}
There has been a continuing discourse about the application of suitable techniques for maintaining peace, law, and order by UN forces around the globe. In Africa for example where regional outfits have been formed to complement UN forces, this has brought to light the ever challenging task of drawing the line between peacekeeping and peace enforcement. In defining these parameters, some scholars have tried to review some of these instances in which traditional peacekeeping techniques became ill suited for the forces on ground thus leading to an extension of peacekeeping mandates to include that of peace-enforcement. From UN missions in the Congo to ECOMOG interventions in West Africa, there is the need to review some of these aspects.
\end{abstract}

Keywords: ECOWAS, ECOMOG, Peacekeeping, Peace enforcement, Conflict

\section{Introduction}

Conflict has often been classified under the headings of: border adjustments or quarrels between neighbours, and internal problems. In Africa for instance such violent activities have unfortunately been on a sufficiently wide scale to make people forget how much of a vast continent has managed to adjust to the changeover to independence from the colonial era with quite remarkable little upheaval. As one writer says, it emanates from the tugs and pulls of differential distribution of resources and access to power and competing definition of what is right, fair and just; which may arise from the pursuit of divergent interests, goals and aspirations by an individual or a group of individuals in their desire to dominate social and physical environment ${ }^{1}$. The response to the perceived threat he adds, could go a long way to determine whether the situation would degenerate into violent or armed conflict or not $^{2}$. According to Dr. Salim A. Salim, a former Secretary General of the Organization of Africa Unity (OAU):

People in conflict situations, at best, live in precarious and uncertain conditions. Conflict are also depriving our continent the use of its immense resources, both human and natural material, at a time when Africa bodily needs the energies of its entire people to forge ahead with its development. Conflicts have torn apart social fabric of the African society. They separated and split families and communities, as millions of our people have been forced to vote with their feet. In sum, the scourge of conflict has been one of the most destabilizing factors and has severely undermined our efforts at promoting socio-economic development. ${ }^{3}$

Despite the strategies evolved by African states towards the settlement of their various conflicts, the history of the continent is full with instances in which foreign intervention in African conflicts have had profound effects on various countries. The history of African since colonization includes a series of self-interest foreign interventions and exploitation of African conflicts by the former Soviet Union and the United States with their respective proxies during the cold war when both super powers carved out spheres of influence and interest in the continent. These interventions more than often prolonged and intensified conflicts in Africa. These states vary greatly in historical experience and in orientation, and they are just beginning to develop patterns of cooperation for common goals. Many proposals for African regional associations have been discussed and few have actually taken organizational form.

Peace on the other hand is the presence of order, law, and tranquility, burtressed on the pillars of social justice, fear of God, social harmony, and love for one's neighbor ${ }^{4}$. According to Nwolise:

Peace is needed for: (i) individuals to have peaceful minds, pursue their legitimate means of livelihood, and develop their potential to the full. (ii) Smooth and full social interaction between individuals and groups within and across nations. (iii) Rapid scientific, technological, and economic development that will positively catalyse the maximization of people's welfare. (iv) The removal of the damages of war. (v) Ending the diversion of development resources from socio-economic needs of citizens to defence and war efforts. (vi) safe trade and interaction... 5

As a result of the humanitarian disasters often created by conflicts e.g. killings, attacks on innocent civilians, rapes, amputations etc. the international community increasingly felt obliged under a common and neutral umbrella to intervene in one way or the other through peace operations and initiatives. Africa has seen so much violence in its history. It has both been a victim and perpetrator of violence. The violence occurred both at 
the structural and physical levels. The Africa security crises have led to many terms of interventions, including the adoption of the peacekeeping strategy, to attempt to achieve conflict resolution. But at the same time, and in other instances the declining attention and support from the outside has also forced African countries through regional partnerships to conduct their own peace support operations, while at the same time trying to draw the line between peace-keeping and peace-enforcement mandates.

\subsection{Peace Keeping}

Peace-keeping has remained one of the strategies of managing conflicts since the Cold War era (19451991) especially during the first half of the 1990s which saw a huge increase in the number and size of UN peace-keeping missions deployed around the globe. The general purpose of peace-keeping operations is to prepare the ground for more lasting solutions to crises, through negotiations among parties in a conflict. This is usually done with representatives from all interested parties, including the intervening forces or groups as the case may be. Peace-keeping, is a way to help countries torn by conflict create conditions for sustainable peace ${ }^{6}$. M. Berdal notes that UN peacekeeping has unique strengths, including legitimacy, burden sharing, and an ability to deploy and sustain troops and police from around the globe, integrating them with civilian peacekeepers to advance multidimensional mandates. Moreover, UN Peacekeepers provide security and the political and peace building support to help countries make the difficult, early transition from conflict to peace while UN Peacekeeping is guided by three basic principles, Consent of the parties; Impartiality; and Non-use of force except in self-defence and defence of the mandate ${ }^{7}$. D. S. Sorenson looked at peacekeeping not only as a means to maintain peace and security, but also to facilitate the political process, protect civilians, assist in the disarmament, demobilization and reintegration of former combatants; support the organization of elections, protect and promote human rights and assist in restoring the rule of law ${ }^{8}$.

The United Nations defines it as an operation involving military personnel, but without power of enforcement, established by an appropriate international body to help maintain peace in an area of conflict 9 . This definition which has an in-built United Nations (U.N.) conception can be understood from the point that at the beginning, there were only the U.N. mounted peace-missions, unlike today when regional and sub-regional organizations send peace-keepers to conflict theatres. Nowadays, the U.N. can either cause such force to be constituted or give its endorsement and support to regional and sub-regional organizations. Peace-keepers monitor and observe peace processes in post-conflict areas and assist ex-combatants in implementing the peaceagreements that they may have signed. Such assistance comes in many forms, including confidence-building measures, power sharing arrangements, electoral support, strengthening the rule of law and economic and social change ${ }^{10}$. From the understanding of what peace-keeping entails, the use of force in peace-keeping operations by peace-keepers is not part of normal peace-keeping.

Accepted principles of the deployment of any U.N. peace-keeping operation or military observer mission is dependent upon it being requested or accepted; without that request or consent there could be no peace-keeping. D. Bowet defines peace-keeping operations as actions of military or non-military nature embarked upon by the U.N. and designed to ensure its maintenance of peace and security in a conflict zone, usually at the invitation, or with the consent, of a host country and such other parties as are embroiled in the conflict $^{11}$. This is not to assume that a peace-keeping force will always enjoy hospitable reception by the warring parties in a conflict zone. In fact, peace-keeping forces have often found themselves targets of brutal attacks from one or the other warring factions when it perceives rightly or wrongly unfavourable tilting of the forces towards its opponent(s). This fact is borne out by the experiences of peace-keeping-forces in the Congo $(1960-1964)$, just as was the case in the more recent ECOMOG operations in Liberia and Sierra-Leone ${ }^{12}$. Peacekeeping in its classical sense as put forward by Nwolise can be defined as:

the application of internationally assembled military, police and relevant civilian personnel in the separation of belligerents in a theatre of violent conflict with the purpose of achieving a cease-fire, and creating an enabling environment for the resolution of the conflict. In this process, the peace-keepers do not use force against any part except for self defence purposes, and operate neutrally and impartially without any interference in the internal affairs of the host country... ${ }^{13}$

Three things should however be stressed. First, peace-keeping was to be conducted only with the consent of the parties concerned, in particular the state upon whose territory the force was to be deployed (the 'host state'), together with the other parties to the specific conflict. Secondly, there was to be the non-use of force except in self-defence. And thirdly, a peace-keeping operation was expected to act with complete impartiality vis-à-vis the parties to the conflict in performing its functions under the UN mandate ${ }^{14}$.

\subsection{Peace-Enforcement}

According to the Encyclopedia Wikipedia, peace-enforcement, like peace-keeping, is a practice of ensuring peace in an area or region. However, peace-enforcement is different from peace-keeping where options, possibly including force are used to bring conflicting parties to negotiations. The concept has however 
attracted a lot of controversy. While it is an approach to maintaining an existing peace, and can thus only be done by an outside party which is recognized as neutral, this is differentiated from peace-keeping largely in the level of force the outside group is willing to use in response to violations of the established peace ${ }^{15}$.Since the beginning of the post-Cold War era, the principle of peace-enforcement in several instances has gradually found itself being applied to environments in which which traditional peace-keeping principles of consent, the non-use of force and impartiality proved ill-suited. As one writer notes:

This led to a vigorous debate among international relations scholars, national defence establishments and the UN Secretariat on such questions as the extent to which these peace-keeping principles, in particular that limiting the use of force to self-defence, could be relaxed. New types of 'peace-keeping' were envisaged for those situations where party cooperation was problematic and the need to use force beyond that for self-defence in fulfilment of mission objectives apparent. ${ }^{16}$

Although the U.N. aims to rid the world of the 'scourge of war', there have been times when it has attempted to enforce the will of the Security Council. Such peace-enforcement is synonymous with activities sanctioned under Chapter VII of the U.N. Charter ${ }^{17}$. Occasionally, the U.N. was not until the 1990s and the dramatic increase in the passage of Chapter VII resolutions that the concept became widely utilized (e.g. Korea in the 1950's, Somalia and Haiti in the 1990's etc) ${ }^{18}$.

R. A. Akindele defines peace-enforcement as the "actual use of force under the auspices of the U.N. to deal with a proven case of armed aggression" $"$. Chapter VII of the U.N. Charter empowers the Security Council to use enforcement measures where considered necessary to maintain international peace ${ }^{20}$. The troops on a peace-keeping mission can be used for peace-enforcement, but the mandate must be changed or extended to cover enforcement action ${ }^{21}$. But as Nwolise adds, "the debate is still on as to whether the troops should not also be changed in such a way that the personnel meant for peace-keeping can be withdrawn, replaced with peaceenforcers, and brought back later to continue peace-keeping" 22 .

While peace-enforcement has largely been avoided in the past, the level of violence which peacekeeping operations in many areas, including 1994 events in Rwanda where several Belgium soldiers were forced to watch the ongoing massacres and were ultimately killed without being allowed to engage, have shocked the international community and lead to crises where willingness to enter peace-keeping operations without the ability to use force is juxtaposed with an unwillingness of nations to enter their forces in potentially 'hot' conflicts which would not otherwise involve them. As is in the case with peacekeeping, in peace-enforcement also the U.N. can either cause such force to be constituted or give its endorsement and support to regional and sub-regional organizations. According to Article 53 of the U.N. Charter:

The Security Council shall appropriately utilize such regional arrangements and agencies for enforcement action under its authority. But no enforcement action shall be taken under the regional arrangements or by agencies without authorization of the Security Council.... ${ }^{23}$

The largest peacekeeping operation undertaken by the U.N. during the Cold War was in the Congo following the formation of the United Nations Operation in the Congo (ONUC) in July of 1960. Prior to the Congo crisis, the majority of the conflicts in various parts of the world were inter-state, and related to territorial disputes which were easily contained by UN observers who were usually not armed. The UN operation in the Congo heralded a significant change, as not only were troops deployed within the borders of a state, but they were also equipped with much heavier armament. In February 1961 the Security Council had authorized the UN to use force to prevent civil war in the Congo, and it demanded withdrawal of all foreign military personnel not under UN command. Opposing the council decision and hoping to forestall further UN intervention, 18 leaders of Congolese factions (not including Gizenga) agreed in March to abolish the central government in favor of a confederation of sovereign states. Consequently and thereafter, the earlier principles of non- interference and self defence changed dramatically, leading to the insertion of armed troops under peace-enforcement as in ECOMOG, and therefore demanding higher standards of training from the participating nations ${ }^{24}$.

At the initial stage, ONUC'S mandate was that of 'stabilization' which within the grounds of traditional peacekeeping, meant the restoration and maintenance of law and order with the consent of the parties involved; and could only use force in self defence. However, ONUC was soon to be given additional powers and functions which it would be argued was to force it over the line dividing peacekeeping and enforcement action. ${ }^{25}$

Thus, following the deteorating climate and continued presence of foreign mercenaries in the province of Katanga, ONUC's mandate was arguably extended with the provision for the use of force (peace enforcement) following Security Council Resolution 169 of 24 November 1961, where in paragraph 4, the Security Council:

Authorizes the Secretary-General to take vigorous action, including the use of the requisite measure of force, if necessary, for the immediate apprehension, detention pending legal action and/or deportation of all foreign military and paramilitary personnel and political advisers not under the United Nations Command, and mercenaries, as laid down in paragraph 2 of Security Council resolution 161 A (1961) of 21 February $1961 \ldots{ }^{26}$ 
The UN force in the Congo launched limited military action against Tshombe's forces in September and again in December of 1961. While trying to arrange a cease-fire between UN and Katangan forces in September, Secretary-General Hammarskjöld was killed under mysterious circumstances in an airplane crash near Ndola, Northern Rhodesia (now Zambia).

However the event in Congo served as an eye opener and an early warning for African states over depending on foreign powers involved in settling disputes and managing conflicts in Africa. In other words, this peace keeping challenge served as a strong motivation for African states to find ways by which Africans problems would be resolved by African methods, without the intervention or dependence of non African powers.

According to Margaret Vogt, when the ECOWAS Monitoring Group (ECOMOG) was assembled and deployed in August 1990 to Liberia, the initial objective of the sub-regional body was the evacuation of the civilian population that was trapped in Liberia, and that the use of Navy strike ships was strictly for convoy protection ${ }^{27}$. ECOMOG was thus, first deployed based on the philosophy of multilateral interventions deriving from humanitarian considerations. In other words, Vogt says that ECOMOG was initially designed to be nonthreatening in order to convince Charles Taylor in particular that it was not an interventionist force deployed in support of Samuel Doe ${ }^{28}$. Upon landing however, Charles Taylor's N.P.F.L. declared war on ECOMOG as he had vowed to do. It was now clear that even without some attempt to protect the force against aggression from the N.P.F.L., the humanitarian responsibility of evacuating stranded civilians from Liberia was going to be an impossible task, and which saw ECOMOG being deployed into an active war zone ${ }^{29}$.

Consequently, from September 29, 1990, ECOMOG's mandate was readjusted to effect the pacification of the country following continued acts of aggression on the civil populace and unprovoked attacks on peace-keepers ${ }^{30}$.

Vogt significantly stresses that though the philosophy of multilateral interventions deriving from humanitarian considerations was initially applied in the Economic Community of West African States Monitoring Group's (ECOMOG's) 1990 intervention in Liberia, Enforcement was pursued until these objectives were achieved, "the enforcement action persuaded the various warring factions to accept a cease-fire agreement under the supervision of ECOMOG and to commence extensive discussions with each other; thus facilitating the convening of the All Liberia Conference from March 15 to April 20 which resulted in the formation of the interim government headed by Dr. Amos Sawyer" ${ }^{\prime 31}$. This shows that it practically became impossible for ECOMOG to achieve its objectives in Liberia without having to apply a measure of force to keep the peace.

M. Weller says that in 1990, ECOMOG began its involvement in the termination of the internal conflict that had then been raging in Liberia for some six months, and that it was only after having ordered a cease-fire and deployed a peace-keeping force in Liberia that ECOWAS reported its action to the U.N. Security Council $^{32}$. Also, he says that throughout its activities relating to Liberia, ECOWAS proceeded to take actions which were only subsequently endorsed by the U.N. Security Council. This practice may mark an important shift in the role of regional organizations within the U.N system, especially when seen in the context of the current attempts to provide for their ever increasing utilization in matters of international peace / security ${ }^{33}$. The Liberia crises, he adds, provides a test case for the proposed devolution of powers to regional agencies ${ }^{34}$.

Weller however argues that the ECOWAS experience has been a mixed one. That is, the peace-keeping and enforcement elements of the operation have attracted considerable controversy. There were allegations of favouritism displayed towards one party to the internal conflicts in Liberia. Also, there were reports concerning the virtual exclusion of humanitarian aid deliveries, except when provided through ECOWAS approved corridors and assertions concerning the failure of ECOWAS to restrain armed factions that, on occasion had been cooperating with $\mathrm{it}^{35}$. Meller says that towards the end of 1993, after an escalation of the conflict in Liberia, it was found necessary to make a fresh start to involve the U.N. peace-keeping operation conducted jointly with a regional organization ${ }^{36}$.

Unfortunately, for the first three years of the Liberian conflict, neither the U.N. as a body nor the individual permanent member States of the U.N. Security Council contributed anything significantly in resolving the conflict. Even when the United States backed by Britain deployed warships to the coast of Liberia in June 1990, the purpose was not to intervene or find a solution but to evacuate their nationals and foreign diplomats ${ }^{37}$. Even when Doe was tortured and murdered in a most barbaric way (as captured on tape and aired throughout Liberia), the U.N. Security Council maintained its silence on Liberia. In January 1991, the Council merely commended the efforts of ECOWAS and called on all parties to the conflict to observe the cease-fire agreement $t^{38}$. It was not until the N.P.F.L. killed five American nuns $\mathrm{s}^{39}$ following continued rebel infiltrations and atrocities before the U.N. Security Council passed Resolution 788 on the 19 of November 1992 which imposed a total embargo on the shipment of weapons and military equipment to Liberia except for those destined for the use of ECOMOG ${ }^{40}$. But it was not until September 1993 that the U.N. took any concrete step in getting involved in the search for the solution to the Liberian conflict. More significantly, this was to be the first time in U.N. history, where the U.N. carried out a combined peace mission with a regional organization. 
The U.N. Security Council issued Resolution 866 approving a 30-man U.N. Observer Mission in Liberia (UNOMIL) as a temporary measure before the deployment an increased 300-man force as an 'expanded' ECOMOG peacekeeping force. Troops from Uganda, Tanzania Zambia and Egypt etc were to take part ${ }^{41}$. In January 1994 following the extension of the UNOMIL's mandate contained in Resolution $866^{42}$, Tanzania for example had deployed 747 troops and a battalion from Uganda (760) had arrived for the ECOMOG expansion ${ }^{43}$. The mandate of UNOMIL was to cooperate with ECOMOG and the O.A.U.

\section{Conclusion}

Conflict has been a recurring problem in the African continent for many years. Consequently these conflicts have led to various interventions, including the adoption of both peacekeeping and peace-enforcement strategies in an attempt to resolve conflicts. Unfortunately, the slow pace of foreign intervention in some instances had led some African states to establish their own regional forces as permitted by the UN. However In the face of humiliation of peacekeeping forces and the continuation of human suffering, there has often been the need to change the mandate of the forces to that of enforcement.

However, the employment of the strategy created an atmosphere in which peace negotiations could be conducted even though this pattern of alternating between peacekeeping and enforcement actions had not been too commonly experienced in other peacekeeping operations.

\section{References}

[1]. Emmanuel Eyeh, Nigeria and Peace Support Operations in Darfur, unpublished M.A. thesis, Nigeria defence Academy, Kaduna, 2009,1 .

[2]. Ibid.

[3]. Salim, Ahamed Salim The Priorities and the Challenges of the OAU on the Eve of the Millennium, Lecture to the German Society for foreign Relations, OAU Conflict Management Bulletin, Vol 1. No 5 August September 1996, 4.

[4]. Ibid.

[5]. Ibid.

[6]. The Blue Helmets, United Nations Department of Public Information (New York, 1958) 3.

[7]. M. R. Berdal and S. Economides, United Nations interventionism, 1991-2004 (London: Cambridge University Press) 246.

[8]. D. S. Sorenson and P. C.Wood The Politics of Peacekeeping in the Post- Cold War Era (London: Psychology Press, 2005$) 26$.

[9]. Bures Oldrich, Regional Peacekeeping Operations: Complementing and Undermining the U.N. Security Council (Oxford: Peace and Security Academy, 2006) 83.

[10]. Ibid

[11]. D. A. Guobadia (quoting Bowet), Legal Dimensions of Peacekeeping Operations, Nigerian Institute of Advanced Legal Studies, 2002, 2

[12]. Bulus Nom Audu, Impact of Nigeria's Foreign Relations on the Armed Forces, 1990-2007, unpublished M.A. thesis, Nigeria Defence Academy, Kaduna, 2009, 73 \& 98.

[13]. Osisioma Nwolise, The Nigerian Military in Peace-Keeping since Independence, in W.T. Gbor (ed.), Military History, Nigeria from Pre-Colonial Era to the Present, (Nigeria: Longman, 2004), 200-201.

[14]. 14. Glenn Steven McDonald: Peace Enforcement: Mapping the 'Middle Ground' in Peace Operations, PhD thesis, University of Genève, 2001, 6

[15]. http://www.en.wikipedia.org/wiki/peace-enforcement, accessed on 28 November, 2008

[16]. 16. Glenn Steven McDonald: Peace Enforcement: Mapping the 'Middle Ground' in Peace Operations, PhD thesis, University of Genève, 2001, 1

[17]. Alex Bellany, et al., Understanding Peace Keeping, (London: Cambridge University Press, 2008$) 8$.

[18]. Ibid.

[19]. Nwolise (quoting Akindele), The Nigerian Military... 202.

[20]. Michael Harbottle, The Blue Berets (London: Leo Cooper 1975) 13.

[21]. Nwolise, (quoting Akindele), The Nigerian Military... 202.

[22]. Ibid.

[23]. United Nations Institute for Disarmament Research, Geneva, UNIDIR/2003/36, p. 105.

[24]. http//www.issafrica.org/Pubs/Other/AfricaCapab/AppendF.html, accessed on $28^{\text {th }}$ April, 2014

[25]. Glenn Steven McDonald: Peace Enforcement: Mapping the 'Middle Ground' in Peace Operations, PhD thesis, University of Genève, 2001, 14

[26]. Ibid., 21.

[27]. Margaret Vogt, The Problems and Challenges of Peace-Making: From Peace-Keeping to Peace-Enforcement, in Vogt (ed.), The Liberian Crisis and ECOMOG-A Bold Attempt at Regional Peace Keeping,(Lagos, Gabumo Publishing Co. Ltd., 1992 ) 154.

[28]. Ibid.

[29]. Ibid., 155

[30]. Ibid. 156

[31]. Ibid.

[32]. M. Weller, Regional Peace-Keeping and International Enforcement: The Liberian Crisis, (London, Cambridge University Press, 1994) 5 .

[33]. Ibid.

[34]. Ibid

[35]. Ibid.

[36]. Ibid., 7 .

[37]. Ibrahim James, ECOMOG under Attack, in Vogt (ed.), the Liberian Crises and ECOMOG... 131.. http//www.un.org/documents/sc/Res/1992/Scres92.htm, accessed on September 24, 2008.

[38]. The Liberian Crisis, report by Justice and Peace Commission, Monrovia, National Catholic Secretariat, July 1994 , p. 35. 
[39]. M. Jumaire and V. Elaigwu, The Evolution of International Peacekeeping and the ECOMOG Operation”, Defence Studies, special issue on ECOMOG,1996, 21.

[40]. Nduba Echezona, International Politics in the Post Cold War Era, (Anambra, Meks Publishers Ltd., 1998) 206.

[41]. http//www.un.org/Docs/Scres/1994/Scres94.htm, accessed on September 24, 2008.

[42]. Echezona, International Politics..., 206. 